\title{
Pengaruh Penggunaan Aplikasi InfoBMKG Terhadap Sikap Tanggap Bencana Mahasiswa Universitas Mataram Pasca Gempa Bumi Lombok
}

\author{
Putri Arifatul Fajriyah ${ }^{1}$, Diyah Indiyati ${ }^{2}$, Agus Purbathin Hadi ${ }^{3}$ \\ ${ }^{1,2,3}$ Program Studi Ilmu Komunikasi Universitas Mataram, Indonesia, putriarifatul26@gmail.com, \\ dewi.indi@gmail.com*, aguspurbathin@gmail.com \\ The Effect of InfoBMKG Application Using Toward Disaster Responsiveness Attitude of \\ Mataram University Students Post Lombok Earthquake
}

\begin{abstract}
This research was carried out after the Lombok earthquake that occurred repeatedly in July and August 2018. In such situations, people need quick and practical information about the earthquake. One of the ways to get practical and fairly accurate information is using the InfoBMKG application. The application is expected to be able to make people more alert and careful about disasters. This study aims to see the effect of using the BMKG Info application on community disaster response attitudes. The object of this research is Universitas Mataram Students. This study uses a quantitative descriptive method on 100 respondents who use the Info BMKG application. Data analysis was done by categorizing data into high, medium, and low, then correlation test to see the relationship, and regression test to see the effect of the variable use of BMKG Info application on disaster response attitude variables. The results of study indicate that there is a strong relationship between the use of the InfoBMKG application and the responsiveness of Universitas Mataram students, and 15.7\% of disaster readiness attitudes of Universitas Mataram students are affected by the use of the InfoBMKG application.
\end{abstract}

Keywords: Lombok earthquake; Info BMKG Application; disaster readiness attitudes

\begin{abstract}
ABSTRAK
Penelitian ini dilakukan setelah peristiwa gempa bumi Lombok yang terjadi berulang kali pada Juli dan Agustus 2018. Dalam situasi seperti itu, masyarakat membutuhkan informasi yang cepat dan praktis mengenai gempa bumi yang terjadi. Salah satu cara mendapatkan informasi yang praktis dan cukup akurat adalah dengan menggunakan aplikasi Info BMKG. Aplikasi tersebut diharapkan dapat membuat masyarakat lebih waspada dan berhati-hati terhadap bencana yang terjadi. Penelitian ini bertujuan melihat pengaruh penggunaan aplikasi Info BMKG terhadap sikap tanggap bencana masyarakat. Objek penelitian ini adalah Mahasiswa Universitas Mataram. Penelitian ini menggunakan metode deskriptif kuantitatif pada 100 orang responden yaitu mahasiswa Universitas Mataram yang menggunakan aplikasi Info BMKG. Analisis data dilakukan dengan pengkategorian data menjadi tinggi, sedang, dan rendah, kemudian uji korelasi untuk melihat hubungan, dan uji regresi untuk melihat pengaruh variabel penggunaan aplikasi Info BMKG terhadap variabel sikap tanggap bencana. Hasil penelitian ini menunjukkan bahwa ada hubungan yang cukup kuat antara penggunaan aplikasi Info BMKG dengan sikap tanggap bencana mahasiswa Universitas Mataram, dan sebesar 15,7\% sikap tanggap bencana mahasiswa Universitas Mataram dipengaruhi oleh penggunaan aplikasi Info BMKG.
\end{abstract}

Kata Kunci : Gempa Lombok; aplikasi InfoBMKG; sikap tanggap bencana

*Corresponding Author

JCommSci Vol 2, Nomor 1,2019, hlm. 1 - 16 


\section{PENDAHULUAN}

Indonesia adalah salah satu negara yang rawan terjadi peristiwa gempa bumi. Hal tersebut karena Indonesia berada pada zona pertemuan empat lempeng tektonik dunia, yaitu Lempeng Eurasia, Indo-Australia, Pasifik dan Filipina (Zulfakriza, 2018). Salah satu peristiwa bencana alam gempa bumi yang terjadi pada tahun 2018 adalah gempa bumi tektonik yang melanda Pulau Lombok pada bulan Agustus. Puncak gempa dengan kekuatan mencapai 7.0 skala richter pada 5 Agustus dan 6.9 skala richter pada 19 Agustus, disertai gempa susulan lainnya menyebabkan kerusakan di beberapa wilayah Pulau Lombok, seperti Kabupaten Lombok Utara, Kabupaten Lombok Timur, Kabupaten Lombok Barat, termasuk di lbu Kota Provinsi NTB yaitu Kota Mataram.

Menurut Badan Nasional Penanggulangan Bencana (BNPB) dalam situsnya (bnpb.go.id, diakses pada 22 Februari 2019), gempa bumi Lombok menimbulkan banyak korban. Jumlah korban meninggal dunia hingga Februari 2019 berjumlah 564 korban jiwa, korban luka-luka berjumlah 1.886 korban, 216.489 rumah rusak, dan total pengungsi berjumlah 472.419 pengungsi.

Badan Meteorologi, Klimatologi dan Geofisika (BMKG) menjadi salah satu lembaga yang memiliki peranan penting saat peristiwa gempa bumi terjadi. Hal ini karena BMKG adalah lembaga yang bertugas menyampaikan informasi dan peringatan dini kepada instansi dan pihak terkait, serta masyarakat, berkenaan dengan bencana yang terjadi karena faktor meteorologi, klimatologi dan geofisika (www.bmkg.go.id, diakses pada 13 November 2018), sehingga dapat dikatakan ketika gempa bumi terjadi, masyarakat bergantung kepada BMKG dalam hal penerimaan informasi gempa bumi, baik itu kekuatan gempa, daerah pusat gempa, potensi yang ditimbulkan pasca gempa (apakah berpotensi tsunami atau tidak), hingga kemungkinan adanya gempa susulan.

Masyarakat tentu membutuhkan Informasi yang cepat dan mudah diakses ketika berada dalam situasi darurat. Oleh karena itu, BMKG meluncurkan aplikasi dengan nama Info BMKG yang memudahkan masyarakat untuk mengetahui berbagai informasi bencana yang terjadi. Kemudahan mengakses informasi ini diharapkan mampu membantu masyarakat mempersiapkan diri untuk menghadapi cuaca buruk atau kemungkinan terjadinya bencana, sehingga meminimalisir dampak yang akan muncul pasca bencana. Saat ini aplikasi Info BMKG telah diunduh oleh lebih dari satu juta pengguna di Google Play Store.

Selain informasi dari BMKG, sikap masyarakat dalam menghadapi bencana juga sangat menentukan dampak pasca bencana. Masyarakat yang tanggap terhadap bencana akan memudahkan dalam penanganan dampak buruknya, misalnya dalam hal penyelamatan dan evakuasi korban, evakuasi harta benda, pemenuhan kebutuhan pokok, dan sebagainya.

Berdasarkan kebutuhan informasi masyarakat terkait bencana yang dapat diperoleh dari aplikasi Info BMKG untuk membantu mempersiapkan diri menghadapi kemungkinan bencana dan membantu mengurangi resiko pasca bencana, timbul pertanyaan oleh peneliti, apakah 
penggunaan aplikasi Info $B M K G$ dapat mempengaruhi sikap tanggap bencana? Atau justru hanya menjadi sarana untuk menerima informasi gempa bumi yang dirasakan masyarakat? Hipotesis yang diuji dalam penelitian ini adalah sebagai berikut :

$\mathrm{H1}$ : Ada pengaruh yang signifikan antara penggunaan aplikasi Info BMKG terhadap sikap tanggap bencana mahasiswa Universitas Mataram.

HO : Tidak ada pengaruh yang signifikan antara penggunaan aplikasi Info BMKG terhadap sikap tanggap bencana mahasiswa Universitas Mataram.

\section{Aplikasi Info BMKG sebagai Media baru}

Media baru atau new media tergolong ke dalam salah satu bentuk komunikasi massa yang merupakan sarana penyalur informasi dengan menggunakan teknologi digital, dimana penyaluran informasinya harus dilakukan secara online. Beberapa bentuk media baru yaitu internet, website, media sosial, dan aplikasi seperti Info BMKG dapat dikatakan sebagai media baru. Aplikasi Info $B M K G$ dapat dikatakan sebagai salah satu wujud media baru karena penyaluran informasinya membutuhkan perangkat yang dapat mengakses jaringan internet. Media baru seperti aplikasi Info BMKG memungkinkan seseorang untuk saling berbagi dengan orang lainnya, misalnya saling berbagi informasi tentang gempa bumi yang baru saja terjadi di daerah pengguna aplikasi, seperti informasi tentang berapa kekuatan gempa dan lokasi pusat gempa.

Aplikasi Info $B M K G$ adalah aplikasi yang dapat digunakan dengan jaringan internet pada perangkat nirkabel atau smartphone, sehingga memungkinkan untuk dilakukannya mobilitas, yang dikeluarkan oleh Badan Meteorologi, Klimatologi, dan Geofisika (BMKG) (bmkg.go.id, diakses pada 13 November 2018) dan dirilis pada 6 Mei 2012. Info BMKG dapat diunduh di Playstore atau App Store. Aplikasi ini dibuat untuk memudahkan masyarakat dalam mendapatkan informasi tentang prakiraan cuaca, iklim, kualitas udara, dan gempa bumi yang terjadi di Indonesia. Aplikasi Info BMKG saat ini telah diunduh oleh lebih dari satu juta pengguna di Playstore dan memperoleh hampir 5 bintang sebagai tanda tingginya rating aplikasi ini di kalangan pengguna android.

Adapun fitur-fitur yang terdapat pada aplikasi Info BMKG antara lain Prakiraan Cuaca, Gempa bumi, Peta Iklim, Kualitas Udara, Cuaca Maritim, Cuaca Bandara, Titik Panas (GeoHotspot), Cuaca Jalur Mudik, Cuaca Event, Peringatan Dini Cuaca, Siaran Pers BMKG, dan Notifikasi dari BMKG. Aplikasi ini juga dapat terhubung langsung dengan website dan berbagai akun media sosial BMKG, mulai dari twitter, instagram, facebook, hingga youtube, yang akan memudahkan pengguna melihat informasi lebih lengkap.

\section{Teori Kegunaan dan Kepuasan (Uses and Gratifications Theory)}

Herbert Blumer dan Elihu Katz adalah yang pertama kali memperkenalkan teori ini pada tahun 1974 dalam buku The Uses on Mass Communications: Current Perspectives on 
Gratification Research (Nurudin, 2014). Teori ini menjelaskan bahwa pengguna media bersifat aktif dan memiliki tujuan tertentu.

Para pengguna media atau khalayak yang aktif menggunakan media tersebut dapat ditandai dengan adanya pilihan-pilihan dengan latar belakang alasan penggunaan yang berbeda-beda. Maksud dari alasan-alasan yang dimaksud tersebut misalnya alasan untuk keluar dari masalah atau aktifitas rutin (escape), mencari informasi (information seeking), mencari hiburan (entertainment), membangun hubungan sosial (social relationship), dan membangun identitas pribadi (personal identity) (Karman, 2013).

Penggunaan media oleh khalayak setelah khalayak memutuskan sendiri akan menkonsumsi informasi apa, memilih media yang mana, berdasarkan keinginannya sendiri, akan menghasilkan kepuasan dalam diri khalayak tersebut, karena keinginannya dalam mendapatkan informasi serta menggunakan media telah terpenuhi.

Teori ini digunakan dalam penelitian ini karena dianggap tepat untuk menggambarkan bagaimana pengguna aplikasi Info BMKG memutuskan untuk menggunakan aplikasi tersebut karena adanya kebutuhan berupa keinginan mendapatkan informasi perihal bencana gempa bumi yang terjadi. Setelah mendapatkan informasi, pengguna aplikasi Info BMKG akan memperoleh kepuasan atas terpenuhinya kebutuhan informasi yang diinginkan.

\section{Teori Adopsi Inovasi}

Inovasi adalah sebuah ide, cara mengerjakan sesuatu, atau benda-benda yang dianggap baru oleh calon pengadopsi, yang bisa merupakan suatu individu, organisasi, atau kelompok. Setiap pilihan dalam proses inovasi ditentukan oleh calon pengadopsi, kondisi sosial dan kultural yang ada (Harun \& Ardianto, 2017). Menurut Everett M. Rogers (dalam Harun \& Ardianto, 2017), elemen-elemen utama dalam analisis difusi suatu inovasi yaitu, inovasi adalah gagasan yang dianggap baru oleh penerima, dikomunikasi melalui saluran-saluran tertentu, di antara anggota-anggota sistem sosial, secara terus menerus atau dapat dikatakan memiliki jangka waktu sampai terjadinya pengadopsian suatu inovasi.

Adopsi merupakan proses pengambilan keputusan oleh individu untuk menolak atau mengadopsi suatu inovasi, mulai dari ketika individu tersebut menyadari adanya suatu inovasi. Adapun lima tahapan dalam proses adopsi bagi individu pengambil keputusan menurut Lionberger (1960), Rogers (1962), Frey (1963), (dalam Harun \& Ardianto, 2017), antara lain : kesadaran, ketertarikan, evaluasi, percobaan, dan adopsi. Terdapat lima kriteria untuk mengadopsi suatu inovasi antara lain keuntungan relatif, kesesuaian, kerumitan/kompleksitas, mudah dicoba, dan mudah diamati.

Teori adopsi inovasi ini digunakan oleh peneliti karena berkaitan dengan inovasi berupa teknologi yang digunakan untuk menyampaikan informasi terkait gempa bumi melalui media, yaitu aplikasi Info BMKG, yang diadopsi oleh masyarakat Lombok, atau dalam hal ini mahasiswa Universitas Mataram. 


\section{Pembentukan Sikap}

Thurstone, Likert, dan Osgood (dalam Azwar, 2016) menyatakan bahwa sikap adalah bentuk reaksi atau evaluasi perasaan yang dapat memihak (favorable) dan tidak memihak (unfavorable) pada suatu objek. Berdasarkan struktur sikap, terdapat tiga komponen yang membentuk sikap yaitu komponen kognitif, komponen afektif, dan komponen konatif. Menurut Azwar (2016), komponen kognitif adalah keyakinan atau kepercayaan seseorang (behavior beliefs dan group belief), komponen afektif adalah komponen yang menyangkut aspek emosional (perasaan), dan komponen konatif atau behavioral adalah aspek yang membuat seseorang cenderung berperilaku sesuai dengan sikapnya. "Komponen afektif atau aspek emosional biasanya berakar paling dalam sebagai komponen sikap, yang paling bertahan terhadap pengaruh-pengaruh yang mungkin mengubah sikap" (Azwar, 2016).

\section{METODE}

Penelitian ini adalah penelitian deskriptif dengan data kuantitatif, yaitu data berupa angka-angka dengan analisis menggunakan statistik (Sugiyono, 2017). Populasi dalam penelitian ini adalah mahasiswa Universitas Mataram yang berjumlah 26.733 mahasiswa. Pengambilan sampel dari populasi tersebut dilakukan dengan purposive random sampling, yaitu pengambilan anggota sampel dari populasi dilakukan dengan pertimbangan atau ketentuan tertentu. Pertimbangan tersebut yaitu calon responden adalah mahasiswa Universitas Mataram yang merupakan pengguna aplikasi Info BMKG. Jumlah sampel yang diambil adalah sebanyak 100 sampel berdasarkan perhitungan menggunakan rumus Taro Yamane dengan toleransi kesalahan $10 \%$ atau 0,1 .

Rumus Taro Yamane :

$$
\begin{gathered}
\mathrm{n}=\frac{N}{N(d)^{2}+1} \\
\mathrm{n}=\frac{26733}{26733(0,1)^{2}+1} \\
\mathrm{n}=99,6 \\
\mathrm{n}=100
\end{gathered}
$$

Ket : $n=$ Sampel

$\mathbf{N}=$ Populasi (Mahasiswa Unram)

$d=$ Presisi $(10 \%$ atau 0,1$)$

Terdapat dua variabel dalam penelitian ini yaitu variabel penggunaan aplikasi Info $B M K G$, serta variabel yaitu sikap tanggap bencana dengan indikator sebagai berikut :

Indikator variabel penggunaan aplikasi Info BMKG:

Buka aplikasi

- Baca konten aplikasi

- Baca notifikasi (pop up)

- Tangkap layar (screenshot) info konten

- Bagi (share) info konten Indikator variabel sikap tanggap bencana :

Pra bencana

- Sikap Kognitif (pengetahuan dan persepsi) 
- Sikap Afektif (perasaan dan motivasi)

- Sikap Konatif (keterampilan bertindak)

Saat bencana

- Sikap Kognitif (pengetahuan dan persepsi)

- Sikap Afektif (perasaan dan motivasi)

- Sikap Konatif (keterampilan bertindak)

Pasca bencana

- Sikap Kognitif (pengetahuan dan persepsi)

- Sikap Afektif (perasaan dan motivasi)

- Sikap Konatif (keterampilan bertindak)

\section{Teknik Pengumpulan Data}

Teknik pengumpulan data pada penelitian ini menggunakan teknik survei dengan memberikan pernyataan dalam bentuk kuesioner kepada responden. Skala yang digunakan dalam instrumen penelitian ini adalah skala likert yang biasa digunakan untuk mengukur sikap, pendapat, dan persepsi seseorangn tentang fenomena sosial (Sugiyono, 2017). Setiap item pertanyaan/pernyataan diberi pilihan jawaban yaitu sangat setuju, setuju, ragu-ragu, tidak setuju, dan sangat tidak setuju, dengan skor masing-masing sebagai berikut

Tabel 1. Pilihan jawaban kuesioner dan skor

\begin{tabular}{ll} 
Pilihan jawaban & Skor \\
\hline Sangat Setuju (SS) & 5 \\
Setuju (S) & 4 \\
Ragu-ragu (R) & 3 \\
Tidak Setuju (TS) & 2 \\
Sangat Tidak Setuju (STS) & 1 \\
\hline
\end{tabular}

\section{Teknik Analisis Data}

Penelitian ini menggunakan analisis statistik nonparametrik karena skala data yang bersifat ordinal. Menurut Junaidi (2015), skala data ordinal sering juga disebut dengan skala peringkat. Hal ini karena dalam skala ordinal, lambang-lambang bilangan hasil pengukuran selain menunjukkan pembedaan juga menunjukkan urutan atau tingkatan obyek yang diukur menurut karakteristik tertentu.

Untuk menganalisis data, hasil jawaban responden untuk setiap variabel akan dikategorisasikan ke dalam kategori tinggi, sedang, dan rendah.. Pengkategorian tersebut dilakukan dengan menentukan range kategori, dengan cara sebagai berikut :

$$
\text { Range }=\frac{\text { skor tertinggi-skor terendah }}{\text { jumlah kategori }}=\frac{5-1}{3}=1,33
$$

Berdasarkan hasil perhitungan range tersebut, diperoleh nilai kategori sebagai berikut :

$$
\begin{aligned}
& \text { Tinggi }=3,68-5 \\
& \text { Sedang }=2,34-3,67 \\
& \text { Rendah }=1-2,33
\end{aligned}
$$


Penentuan hasil jawaban responden yang masuk ke dalam tiap kategori tersebut dilakukan dengan:

total skor satu orang responden

$\overline{\text { jumlah item pernyataan kuesioner }}$

Untuk mengetahui jumlah persentase jawaban responden yang masuk kriteria tinggi, sedang, dan rendah, maka digunakan rumus sebagai berikut : Persentase = Frekuensi / N x 100

Untuk menganalisis data, penelitian ini akan menggunakan rumus Korelasi Spearman Rank yang dihitung dengan aplikasi SPSS. Korelasi Spearman Rank digunakan untuk mengetahui ada atau tidaknya hubungan antar dua variabel, serta untuk mengetahui arah hubungan variabel tersebut.

Jika hasil perhitungan menggunakan aplikasi SPSS menunjukkan nilai signifikansi $<0,1$, maka dapat dikatakan ada hubungan antara variabel $X$ dengan variabel $Y$. Jika nilai signifikansi > 0,1 , maka tidak ada hubungan antara variabel $X$ dengan variabel $Y$. Jika nilai koefisien korelasi rank spearman menunjukkan nilai positif, berarti hubungan kedua variabel dikatakan searah, yaitu apabila nilai variabel $x$ meningkat, maka variabel y juga akan meningkat, begitu pula sebaliknya.

Adapun pedoman kekuatan hubungan antar variabel (correlation coefficient) adalah sebagai berikut :

$$
\begin{aligned}
& 0,00-0,25=\text { Hubungan lemah } \\
& 0,26-0,50=\text { Hubungan cukup kuat } \\
& 0,51-0,75=\text { Hubungan kuat } \\
& 0,76-0,99=\text { Hubungan sangat kuat } \\
& \begin{aligned}
1,00 & =\text { Hubungan sempurna }
\end{aligned}
\end{aligned}
$$

Semakin mendekati 0, hubungan antar variabel semakin lemah. Sebaliknya, semakin mendekati 1, hubungan menjadi semakin kuat (Sarwono \& Salim, 2017).

Selanjutnya, setelah digunakan rumus korelasi spearman rank untuk melihat hubungan, peneliti akan melakukan uji regresi untuk melihat ada atau tidaknya pengaruh antara variabel bebas dan variabel terikat, demi menjawab pertanyaan penelitian ini. Uji regresi linier sederhana dilakukan menggunakan aplikasi SPSS. Untuk melihat ada atau tidaknya pengaruh antara kedua variabel, maka koefisien regresi harus signifikan. Koefisien regresi dikatakan signifikan jika t hitung $>\mathrm{t}$ tabel (Sarwono \& Salim, 2017). Adapun t tabel pada penelitian ini senilai 1,98447 .

\section{HASIL DAN PEMBAHASAN}

Peristiwa gempa bumi di Lombok yang terjadi pada tahun 2018 dimulai pada akhir bulan Juli, tepatnya pada 29 Juli dengan kekuatan gempa mencapai 6,4 SR. Gempa tersebut kemudian disusul oleh peristiwa gempa bumi lainnya yang terjadi berkali-kali. Bahkan BMKG menyebutkan bahwa setidaknya ada 585 gempa susulan, baik yang dirasakan atau tidak 
dirasakan oleh masyarakat Lombok yang terjadi saat itu, hingga pada tanggal 5 Agustus terjadi lagi gempa dengan kekuatan lebih dari 5,5 SR, yaitu berkekuatan 7 SR dan disebut sebagai main shock, karena gempa tersebut memiliki kekutan terbesar dibanding gempa-gempa sebelumnya. Meski demikian, masih terdapat beberapa gempa susulan yang terjadi setelah tanggal 5 Agustus, dengan kekuatan yang lebih kecil.

Gempa-gempa tersebut menimbulkan korban jiwa sebanyak 564 korban dan kerugian materi, termasuk rusaknya bangunan-bangunan sehingga menghambat aktifitas masyarakat Lombok. Kerusakan bangunan juga terjadi di Universitas Mataram yang mengakibatkan terhambatnya kegiatan perkuliahan. Selain itu, gempa bumi tersebut juga menimbulkan trauma di kalangan masyarakat sehingga banyak masyarakat yang memilih untuk tinggal sementara di tenda-tenda yang dibangun di sekitar tempat tinggalnya.

Gempa bumi yang terjadi berkali-kali dalam kurun waktu kurang lebih dua bulan mengharuskan masyarakat untuk lebih waspada dan tanggap terhadap gempa bumi yang terjadi. Hal itulah yang membuat masyarakat mulai menggunakan aplikasi Info BMKG sebagai salah satu cara untuk lebih waspada dengan memantau informasi gempa dari berbagai media, salah satunya dari aplikasi Info BMKG.

Masyarakat Lombok menggunakan aplikasi Info BMKG untuk melihat informasi gempa bumi yang terjadi, seperti kekuatan gempa, jarak lokasi pengguna dengan pusat gempa, serta potensi ancaman yang ditimbulkan pasca gempa, misalnya ancaman tsunami. Situs web dan media sosial BMKG juga memudahkan masyarakat untuk mengetahui informasi lebih lengkap terkait gempa bumi tersebut. Situs web dan media sosial BMKG tersebut pun telah terhubung langsung dengan aplikasi Info BMKG yang semakin mempermudah masyarakat mengakses informasi.

Meski demikian, dampak penggunaan aplikasi tersebut juga bukan hanya menjadikan masyarakat lebih waspada, namun juga dapat menimbulkan kepanikan di masyarakat, terutama jika informasi yang diperoleh adalah terkait potensi ancaman setelah gempa, misalnya adanya peringatan tsunami.

Saat peristiwa gempa 7 SR tersebut, sempat beredar informasi bahwa akan terjadi tsunami sehingga membuat warga panik, khususnya warga di wilayah Ampenan dan Kota Mataram. Menurut kepala BMKG, Dwikorita Karnawati, gempa tersebut memang berpotensi tsunami, namun pada level paling rendah yaitu level waspada, dengan ketinggian gelombang tsunami maksimal setengah meter atau $50 \mathrm{~cm}$ (https://www.liputan6.com, diakses pada 24 Februari 2019). Meski demikian, masyarakat yang sudah terlanjur panik banyak yang memutuskan untuk mengungsi ke daerah yang dirasa lebih aman, sehingga sempat menyebabkan kemacetan cukup parah di wilayah kota Mataram dan Lombok Barat

\section{Penggunaan Aplikasi Info BMKG}

Aplikasi Info BMKG merupakan aplikasi yang dibuat untuk memudahkan masyarakat dalam mengakses informasi terkait perkiraan kondisi alam, seperti prakiraan cuaca, kualitas 
udara, iklim, gempa bumi, dan sebagainya yang berkaitan dengan meteorologi, klimatologi, dan geofisika. Terkait peristiwa gempa bumi Lombok tahun 2018, aplikasi ini menjadi salah satu sarana penyalur informasi yang banyak digunakan oleh masyarakat Lombok, khususnya mahasiswa Universitas Mataram untuk melihat informasi gempa bumi yang terjadi, terutama mengenai berapa kekuatan gempa, lokasi pusat gempa, kedalaman gempa, dan potensi ancaman yang ditimbulkan pasca gempa.

Apabila dikaitkan dengan lima kriteria untuk mengadopsi suatu inovasi, maka aplikasi Info $B M K G$ diadopsi oleh mahasiswa Universitas Mataram dengan alasan sebagai berikut :

1) Keuntungan relatif

Pengadopsian inovasi berupa aplikasi Info $B M K G$ adalah karena para pengguna akan memperoleh keuntungan berupa terpenuhinya kebutuhan informasi terkait info gempa bumi, yang akan menjadikan pengguna lebih siaga atau tanggap terhadap potensi ancaman gempa bumi tersebut.

2) Kesesuaian

Aplikasi Info BMKG sesuai dengan kebutuhan mahasiswa Universitas Mataram karena berkaitan dengan pengalaman mereka yaitu perstiwa gempa bumi yang berkali-kali, membuat mereka semakin membutuhkan informasi yang cepat dan praktis terkait gempa.

3) Kerumitan/kompleksitas

Aplikasi Info BMKG sebagai sebuah inovasi memiliki tingkat kompleksitas yang rendah, terutama bagi kalangan mahasiswa sebagai generasi muda yang lebih melek teknologi. Kemudahan dalam penggunaan aplikasi ini membuat aplikasi Info BMKG sebagai sebuah inovasi semakin mudah diterima atau diadopsi.

4) Mudah dicoba

Aplikasi Info $B M K G$ sangat mudah diuji coba penggunaannya karena cukup dengan mengunduh aplikasi tersebut di playstore untuk pengguna android, atau app store untuk pengguna iphone.

5) Mudah diamati

Aplikasi Info BMKG dapat dengan mudah dilihat kegunaan dan keunggulannya karena pengguna aplikasi ini juga banyak, yaitu sebanyak lebih dari 1,8 juta pengguna aktif di seluruh Indonesia, serta karena kemudahan dalam mendapatkan aplikasi tersebut, yaitu dengan mengunduhnya saja di Playstore atau app store dengan gratis.

Setelah dilakukan penyebaran kuesioner secara langsung kepada 100 responden, diperoleh hasil jawaban responden pada kuesioner tersebut yang selanjutnya dianalisis untuk dikategorikan ke dalam kategori penggunaan aplikasi Info BMKG yang tinggi, sedang, dan rendah. Perhitungan tersebut memberikan hasil sebagai berikut : 
Tabel 2. Distribusi frekuensi dan persentase jawaban pada variabel $X$ (penggunaan aplikasi Info BMKG)

\begin{tabular}{cccc} 
Kategori & Kriteria & Frekuensi & Persentase \\
\hline Tinggi & $3,68-5$ & 24 & $24 \%$ \\
Sedang & $2,34-3,67$ & 72 & $72 \%$ \\
Rendah & $1-2,33$ & 4 & $4 \%$ \\
& Jumlah & 100 & $100 \%$ \\
\hline
\end{tabular}

Tabel 2 di atas menunjukkan bahwa penggunaan aplikasi Info BMKG di kalangan mahasiswa Univeritas Mataram dominan tergolong ke dalam kategori penggunaan sedang, dengan persentase responden sebanyak $72 \%$. Sedangkan penggunaan tinggi berjumlah $24 \%$, dan penggunaan rendah berjumlah $4 \%$.

Berdasarkan hasil tersebut, dapat dikatakan bahwa penggunaan aplikasi Info BMKG secara garis besar tergolong sedang, karena kebanyakan para responden, yaitu mahasiswa Universitas Mataram, menggunakan aplikasi Info BMKG hanya saat ada notifikasi tentang gempa saja (pasca gempa) yang muncul di smartphone mereka. Selain itu, para responden juga kebanyakan hanya membaca konten tertentu, yaitu konten tentang gempa saja, yang terjadi di daerah mereka. Para responden juga kebanyakan lebih memilih membagikan info konten aplikasi yang telah discreenshot ke aplikasi instant messaging dan media sosial dibanding membagikannya langsung lewat aplikasi.

Penggunaan aplikasi Info $B M K G$ oleh mahasiswa Universitas Mataram adalah karena pengguna ingin memperoleh informasi yang cepat dan praktis, dimana pun, kapan pun, cukup dengan membuka aplikasi Info $B M K G$ pada smartphone masing-masing. Informasi yang diperoleh dari Info BMKG pun dianggap lebih terpercaya, karena informasi tersebut berasal dari BMKG yang merupakan lembaga resmi dengan tugas memberikan informasi mengenai hal-hal terkait peristiwa bencana, termasuk gempa bumi.

Meski demikian, info dari aplikasi tersebut pun terkadang masih telat diterima oleh pengguna aplikasi, karena faktor dari BMKG sendiri atau juga dipengaruhi faktor jaringan internet pengguna. Penggunaan aplikasi Info BMKG secara khusus dikarenakan adanya kebutuhan untuk memperoleh informasi terkait gempa bumi yang terjadi di Pulau Lombok. Para pengguna secara umum menggunakan aplikasi untuk melihat fitur khusus gempa, dan bertujuan melihat jarak lokasi pusat gempa dengan lokasi pengguna, besar kekuatan gempa, dan potensi ancaman yang kemungkinan akan ditimbulkan setelah gempa.

Berkaitan dengan landasan teori yang digunakan dalam penelitian ini yaitu, teori Uses and Gratifications, yang mengasumsikan bahwa pengguna media atau dalam hal ini pengguna aplikasi Info $B M K G$ memiliki tujuan tertentu dalam penggunaan aplikasi tersebut. Para pengguna memiliki latar belakang atau alasan yang berbeda-beda. Misalnya alasan untuk keluar dari masalah atau aktifitas rutin (escape), mencari informasi (information seeking), mencari 
hiburan (entertainment), membangun hubungan sosial (social relationship), dan membangun identitas pribadi (personal identity) (Karman, 2013).

Pengguna aplikasi Info BMKG ini memiliki alasan untuk menggunakan aplikasi tersebut karena kebutuhan untuk keluar dari masalah berupa kecemasan saat gempa bumi terjadi, seperti kecemasan tentang kemungkinan adanya gempa bumi susulan atau potensi tsunami. Selain itu, alasannya juga karena kebutuhan untuk memperoleh informasi terkait gempa bumi yang terjadi. Pengguna aplikasi Info BMKG memutuskan sendiri akan menkonsumsi informasi apa, berdasarkan keinginannya sendiri, dan kemudian akan menghasilkan kepuasan dalam diri pengguna tersebut, karena keinginannya dalam memperoleh informasi serta menggunakan media telah terpenuhi.

Selain itu, penggunaan aplikasi Info BMKG merupakan wujud dari adanya adopsi inovasi sebuah media baru, di mana informasi seputar bencana yang disampaikan oleh BMKG sebagai lembaga yang berwenang menjadi lebih mudah diakses oleh para pengguna, terutama bagi kalangan anak muda seperti mahasiswa Universitas Mataram, dengan cukup membuka aplikasi Info BMKG pada HP atau smartphone mereka sendiri.

Berdasarkan lima tahapan dalam proses adopsi inovasi bagi calon adopter menurut Lionberger (1960), Rogers (1962), Frey (1963), (dalam Harun \& Ardianto, 2017), yaitu tahap kesadaran, ketertarikan, evaluasi, percobaan, dan adopsi, dapat dijelaskan bahwa dalam penelitian ini, pada tahap kesadaran, calon pengguna aplikasi yaitu mahasiswa Universitas Mataram menyadari adanya sebuah inovasi berupa aplikasi Info BMKG. Kesadaran akan adanya informasi ini dipengaruhi oleh berbagai faktor, termasuk media massa maupun faktor interpersonal. Selanjutnya, calon pengguna kemudian menuju tahap ketertarikan dengan mencari tahu berbagai informasi lengkap mengenai aplikasi tersebut. Kemudian calon pengguna mengevaluasi dan memutuskan secara mental apakah aplikasi tersebut cocok dengan dirinya atau tidak, sesuai dengan kebutuhannya atau tidak, sehingga calon pengguna akan menuju ke tahap percobaan untuk mencoba bagaimana inovasi tersebut jika digunakan atau diterapkan dalam kehidupannya. Setelah percobaan, pengguna akan memutuskan untuk mengadopsi secara menyeluruh inovasi tersebut. Pada ketiga tahapan terakhir ini, yang paling dominan mempengaruhi adalah faktor interpersonal, karena orang-orang di sekitarnya banyak menggunakan aplikasi tersebut, sehingga calon pengguna dapat mudah melihat keunggulan dan manfaat yang dimiliki aplikasi Info BMKG, sampai akhirnya memutuskan untuk ikut menggunakan.

Banyaknya jumlah pengguna aktif aplikasi Info $B M K G$, tidak menjamin penggunaannya akan bertahan dalam jangka waktu yang lebih lama. Hal ini dapat dilihat dari adanya diskontinuansi atau tindakan berhenti mengadopsi aplikasi Info BMKG oleh beberapa mahasiswa Universitas Mataram dengan alasan sudah tidak membutuhkan informasi tentang gempa. Beberapa mahasiswa mengatakan bahwa gempa bumi sudah tidak terjadi lagi sehingga mereka memutuskan untuk menghapus aplikasi tersebut dari perangkat selulernya. Selain itu, 
alasan lain terjadinya diskontinuansi penggunaan aplikasi Info BMKG ini adalah karena alasan mampu mendapatkan informasi yang lebih detail dengan cukup membuka media sosial atau web BMKG langsung, tanpa melalui aplikasi.

\section{Sikap Tanggap Bencana}

Sikap tanggap bencana atau tanggap darurat bencana adalah sikap untuk mengantisipasi berbagai kemungkinan yang tidak diinginkan yang akan menimbulkan kerugian akibat bencana (www.academia.edu, diakses pada 10 Desember 2018), atau dalam penelitian ini adalah bencana gempa bumi.

Sikap tanggap bencana dapat berupa tindakan perlindungan diri dan orang sekitar, penyelamatan diri dan orang sekitar, evakuasi korban, penyelamatan harta benda, pemenuhan kebutuhan dasar, pengurusan pengungsi, serta pemulihan sarana dan prasarana.

Ramli (2010) juga menkonsepkan tanggap darurat bencana yaitu "Serangkaian kegiatan yang dilakukan dengan segera pada saat kejadian bencana untuk menangani dampak buruk yang ditimbulkan, yang meliputi kegiatan penyelamatan dan evakuasi korban, harta benda, pemenuhan kebutuhan dasar, perlindungan, pengurusan pengungsi, penyelamatan, serta pemulihan prasarana dan sarana".

Penyusunan kategori sikap tanggap bencana mahasiswa Universitas Mataram yang dilakukan kepada tiap responden yang berjumlah 100, dengan menggunakan aplikasi Microsoft Excel memberikan hasil sebagai berikut :

Tabel 3. Distribusi frekuensi dan persentase jawaban pada variabel $Y$

(sikap tanggap bencana)

\begin{tabular}{llll}
\hline Kategori & Kriteria & Frekuensi & Persentase \\
\hline Tinggi & $3,68-5$ & 71 & $71 \%$ \\
Sedang & $2,34-3,67$ & 29 & $29 \%$ \\
Rendah & $1-2,33$ & 0 & $0 \%$ \\
& Jumlah & 100 & $100 \%$ \\
\hline
\end{tabular}

Berdasarkan Tabel 3 tersebut, dapat diketahui bahwa sikap tanggap bencana mahasiswa Universitas Mataram secara umum yang meliputi sikap kognitif, afektif, dan konatif, sebagian besar berada dalam kategori tinggi, dengan persentase jumlah responden sebesar 71\%, sedangkan kategori sedang berjumlah 29\%, dan kategori rendah berjumlah 0\% alias tidak ada responden yang jumlah skornya masuk dalam kategori rendah.

Berdasarkan hasil tersebut, dapat dikatakan bahwa sikap tanggap bencana mahasiswa Universitas Mataram tergolong ke dalam kategori tinggi karena mahasiswa mengetahui tindakan yang harus diambil saat gempa terjadi, seperti menghindari berbagai benda-benda yang kemungkinan dapat menimpa. Tindakan penyelamatan diri tersebut dilakukan sesuai informasi yang diakses melalui web atau media sosial BMKG yang terhubung dengan aplikasi. Selain itu, mahasiswa juga mengetahui berbagai potensi ancaman gempa melalui aplikasi Info 
$B M K G$, atau dengan kata lain mahasiswa akan bersikap lebih tanggap terhadap gempa bumi setelah melihat potensi ancaman pasca gempa yang ditunjukkan oleh aplikasi, misalnya potensi ancaman berupa tsunami. Hal ini dapat dibuktikan dengan peristiwa gempa bumi Lombok tahun 2018 ketika terjadi gempa berkekuatan 7 SR dengan potensi tsunami, membuat masyarakat langsung mengambil tindakan untuk menyelamatkan diri menuju ke daerah yang dianggap lebih aman.

\section{Hasil Uji Korelasi}

Menurut hasil uji korelasi spearman rank untuk melihat hubungan dari kedua variabel dengan aplikasi SPSS, diketahui bahwa nilai signifikansi sebesar .001 atau sig =0,001, sehingga dapat dikatakan ada hubungan yang signifikan antara variabel $X$ dan variabel Y. Selain itu, nilai koefisien korelasi sebesar .320, yang berarti bahwa besar korelasi antara variabel penggunaan aplikasi Info BMKG dengan variabel sikap tanggap bencana yaitu sebesar 0.320 atau hubungan cukup, sesuai dengan pedoman kekuatan hubungan antar variabel (correlation coefficient) yang telah dicantumkan pada bab sebelumnya, yaitu sebagai berikut :

$$
\begin{aligned}
0,00-0,25 & =\text { Hubungan lemah } \\
0,26-0,50 & =\text { Hubungan cukup kuat } \\
0,51-0,75 & =\text { Hubungan kuat } \\
0,76-0,99 & =\text { Hubungan sangat kuat } \\
1,00 & =\text { Hubungan sempurna }
\end{aligned}
$$

Untuk melihat arah hubungan antar variabel, apakah searah atau tidak, dapat diketahui dari angka koefisien korelasinya yang menunjukkan nilai positif atau negatif (Sarwono \& Salim, 2017). Karena angka koefisien korelasinya menunjukkan nilai positif, yaitu 0,320, maka dapat dikatakan bahwa korelasi kedua variabel bersifat searah. Maksudnya, apabila penggunaan aplikasi Info BMKG tinggi, maka sikap tanggap bencana mahasiswa Universitas Mataram juga akan tinggi. Misalnya ketika pengguna aplikasi semakin sering menggunakan aplikasi untuk mencari tahu berbagai tindakan mitigasi bencana, maka sikap tanggap bencana pengguna juga meningkat yaitu berupa pemahaman terkait berbagai tindakan siaga bencana yang dapat dilakukan saat terjadi gempa bumi, sehingga dalam praktiknya pun akan lebih mudah.

\section{Hasil Uji Regresi}

Setelah dilakukan uji korelasi untuk melihat hubungan, peneliti melakukan uji regresi untuk melihat ada atau tidaknya pengaruh antara variabel independen dan variabel dependen. Uji regresi linier sederhana dilakukan menggunakan aplikasi SPSS. Berikut hasil uji regresi:

Tabel 4. Koefisien Determinasi

\begin{tabular}{l|c|cr|c} 
Model & R & R Square & Adjusted R Square & \multicolumn{2}{c}{$\begin{array}{c}\text { Std. Error of the } \\
\text { Estimate }\end{array}$} \\
\hline 1 & $.396^{\mathrm{a}}$ & .157 & .148 & 12.533 \\
\hline a. Predictors: (Constant), Penggunaan aplikasi Info BMKG & &
\end{tabular}


Angka $\mathrm{R}$ Square (angka korelasi yang dikuadratkan) atau disebut juga koefisien determinasi pada tabel 4.8 yaitu sebesar 0.157 atau sama dengan 15,7\%. Angka tersebut berarti bahwa $15,7 \%$ sikap tanggap bencana dipengaruhi oleh penggunaan aplikasi Info BMKG. Sedangkan sisanya, yaitu sebesar $84,3 \%$ (100\% - 15,7\%) dipengaruhi oleh faktor lain.

Tabel 5. Koefisien Regresi

\begin{tabular}{|c|c|c|c|c|c|c|}
\hline \multicolumn{7}{|c|}{ Coefficients $^{a}$} \\
\hline & & \multicolumn{2}{|c|}{ Unstandardized Coefficients } & \multirow{2}{*}{$\begin{array}{l}\text { Standardized } \\
\text { Coefficients } \\
\text { Beta }\end{array}$} & \multirow[b]{2}{*}{$\mathrm{t}$} & \multirow[b]{2}{*}{ Sig. } \\
\hline \multicolumn{2}{|c|}{ Model } & B & Std. Error & & & \\
\hline \multirow[t]{2}{*}{1} & (Constant) & 92.396 & 8.588 & & 10.759 & .000 \\
\hline & $\begin{array}{l}\text { Penggunaan aplikasi Info } \\
B M K G\end{array}$ & .401 & .094 & .396 & 4.265 & .000 \\
\hline
\end{tabular}

a. Dependent Variable: Sikap tanggap bencana

Tabel 4.4 menunjukkan persamaan regresi untuk mengetahui angka konstan, dimana angka konstannya yaitu sebesar 92,396, sedangkan nilai koefisien regresi penggunaan aplikasi Info $B M K G$ adalah sebesar 0,401 . Sehingga didapatkan persamaan regresi sebagai berikut :

$Y=a+b X$
$Y=92,396+0,401 X$

Ket :

$Y=$ sikap tanggap bencana,

$\mathrm{X}=$ penggunaan aplikasi Info $B M K G$.

$\mathrm{a}=$ angka konstan sebesar 92,936 (nilai konsisten dari variabel sikap tanggap bencana)

$\mathrm{b}=$ koefisien regresi, yaitu sebesar 0,401

Koefisien regresi tersebut menunjukkan bahwa setiap penambahan $1 \%$ nilai penggunaan aplikasi Info BMKG, maka sikap tanggap bencana akan meningkat sebesar 0,401. Karena angka koefisien regresi adalah positif, maka arah pengaruh variabel $X$ terhadap variabel $Y$ juga positif.

Berdasarkan nilai signifikansi, dari tabel 4.10 tersebut diperoleh nilai signifikansi sebesar 0,000 yang berarti ada pengaruh variabel penggunaan aplikasi Info BMKG terhadap variabel sikap tanggap bencana. Selain itu, dengan melihat nilai t hitung yang menunjukkan angka 4,265, berarti koefisien regresi dikatakan signifikan karena nilainya lebih dari t tabel. Dengan demikian, maka dalam penelitian ini $\mathrm{HO}$ ditolak dan $\mathrm{H} 1$ diterima, karena hasil penelitian menunjukkan ada pengaruh yang signifikan antara penggunaan aplikasi Info BMKG terhadap sikap tanggap bencana pada mahasiswa Universitas Mataram.

\section{SIMPULAN}

Penggunaan aplikasi Info BMKG dikalangan mahasiswa Universitas Mataram tergolong ke dalam kategori penggunaan sedang hanya digunakan saat ada notifikasi tentang gempa saja (pasca gempa) serta hanya membaca konten tertentu, yaitu konten tentang gempa saja, yang terjadi di daerah mereka. Para responden juga kebanyakan lebih memilih membagikan info 
konten aplikasi yang telah discreenshot ke aplikasi instant messaging dan media sosial dibanding membagikannya langsung lewat aplikasi. Setelah menggunakan aplikasi Info BMKG, para responden akan merasa lebih puas karena kebutuhan mereka akan informasi telah diperoleh.

Sikap tanggap bencana mahasiswa Universitas Mataram tergolong ke dalam kategori tinggi karena mahasiswa mengetahui tindakan yang harus diambil saat gempa terjadi, seperti menghindari berbagai benda-benda yang kemungkinan dapat menimpa. Tindakan penyelamatan diri tersebut dilakukan sesuai informasi yang diperoleh dari web atau media sosial BMKG yang terhubung dengan aplikasi. Selain itu, mahasiswa juga mengetahui berbagai potensi ancaman gempa berkat aplikasi Info BMKG, atau dengan kata lain mahasiswa akan bersikap lebih tanggap terhadap gempa bumi setelah melihat potensi ancaman pasca gempa yang ditunjukkan oleh aplikasi, misalnya potensi ancaman berupa tsunami. Analisis korelasi atau hubungan antara penggunaan aplikasi Info BMKG dengan sikap tanggap bencana mahasiswa Universitas Mataram menunjukkan nilai hubungan yang cukup, artinya hubungannya tidak begitu besar. Sedangkan untuk hasil analisis regresi menunjukkan bahwa sikap tanggap bencana dipengaruhi oleh penggunaan aplikasi Info BMKG dengan kekutan pengaruh sebesar $15,7 \%$.

\section{DAFTAR PUSTAKA}

Ali M. (2018). BMKG: Gelombang Tsunami Akibat Gempa 7 SR Lombok Maksimal $50 \mathrm{Cm}$. news/read/3610473/bmkg-gelombang-tsunami-akibat-gempa-7-sr-lombok-maksimal50-cm. [Diakses pada 24 Februari 2019].

Azwar S. (2016). Sikap Manusia, Teori dan Pengukurannya. Edisi ke-2, Cetakan ke-XXI. Pustaka pelajar. Yogyakarta.

BMKG. (2018). Tugas dan Fungsi. https://www.bmkg.go.id/profil/?p=tugas-fungsi. [Diakses pada 13 November 2018].

.(2018). Layanan Jaringan Komunikasi. https://www.bmkg.go.id/jaringankomunikasi/?p=layanan. [Diakses pada 13 November 2018].

Harun R., Ardianto E. (2017). Komunikasi Pembangunan dan Perubahan Sosial. Cetakan ke-3, Juni 2017. PT RajaGrafindo Persada. Depok.

Junaidi. (2015). Memahami Skala-skala Pengukuran. https://www.researchgate.net/publication/277340990_Memahami_SkalaSkala_Pengukuran. [Diakses pada 15 November 2018]. 
Karman. (2013). Riset Penggunaan Media dan Perkembangannya Kini. Vol. 17 No. 1. https://jurnal.kominfo.go.id/index.php/jskm/article/view/170106/119. [Diakses pada 13 November 2018].

Nurudin. (2007). Pengantar Komunikasi Massa. Cetakan ke-6. PT RajaGrafindo Persada. Jakarta.

Ramli S. (2010). Pedoman Praktis Manajemen Bencana (Disaster Management). Dian Rakyat. Jakarta.

Sarwono J., Salim H.N. (2017). Prosedur-prosedur Popular Statistik untuk Analisis Data Riset Skripsi. Penerbit Gava Media. Yogyakarta.

Sugiyono. (2017). Metode Penelitian Kuantitatif, Kualitatif, dan R\&D. Cetakan ke-25. Alfabeta. Bandung. . (2017). Statisika untuk Penelitian. Cetakan ke-28. Alfabeta. Bandung.

Vera N. (2016). Komunikasi Massa. Penerbit Ghalia Indonesia. Bogor.

Wardani, T.L. (2018). Tanggap darurat. https://www.academia.edu/34486127/TANGGAP DARURAT. [Diakses pada 10 Desember 2018].

Zulfakriza. (2018). Gempa Bumi, Mungkinkah Diprediksi?. https://sains.kompas.com/read/2018/02/02/182603623/gempa-bumi-mungkinkahdiprediksi. [Diakses pada 13 Desember 2018]. 